\title{
ANALISIS PROSES PEMBELAJARAN POKOK BAHASAN ELEKTROKIMIA DI KELAS XII SMAN 1 PANTI
}

\author{
Indang Dewata ${ }^{1}$ dan Nike Okmi Melyanti ${ }^{2}$ \\ Jurusan Kimia Universitas Negeri Padang \\ Korespondensi:. Jl. Lettu Didik Nomor 1A, Kota Solok, Email: i_dewata@yahoo.com
}

\begin{abstract}
The purpose of this research was to analyze the learning process of electrolysis cell matter which covered the planning, implementation, and evaluation; and analysis of the understanding of students' concept (conception) as well as the finding of the cause of the misconceptions and not understanding in matter of electrolysis cell. The study used was descriptive analysis. It was used to answer the problem's formulation in this study. The object of this research were the process of learning and students' conceptions. The subjects of this study were students in grade XII LA I and LA II and chemistry teacher in grade XII LA at SMAN 1 Panti. Instruments in this study were the observation guide, a recorder (Handycam) and two tier diagnostic test.Based on the data analysis, it is found that (1) learning process in the electrolysis cell matter in SMAN 1 Panti was not in accordance with the standards of process (2) Students LA I and LA II had misconceptions and did not understand the whole concept in electrolysis cell matter. (3) The cause of misconceptions and not understanding of students were mainly the teachers and students. The learning process should be conducted in accordance with the standards of process that has been established by government in order to ensure learning carried out effectively, so the quality of learning can be improved.
\end{abstract}

Kata kunci: analisis, proses pembelajaran, elektrokimia

\section{PENDAHULUAN}

$\mathrm{S}$ alah satu penjabaran tujuan pendidikan nasional adalah tujuan pendidikan kimia yang lebih mengutamakan penguasaan konsep dan saling keterkaitannya serta bersikap ilmiah untuk memecahkan masalah yang dihadapinya. Dilihat dari kenyataan yang ada, ternyata tujuan pendidikan kimia tersebut belum sepenuhnya tercapai. Salah satu penyebab yang cukup berpengaruh terhadap pencapaian tujuan pendidikan kimia adalah proses pembelajaran kimia yang tidak memperhatikan pemahaman konsep siswa yang berakibat pada rendahnya hasil belajar. Proses pembelajaran merupakan faktor utama yang mempengaruhi hasil belajar. Proses pem- belajaran dilaksanakan sesuai dengan standar proses menurut Permendiknas Nomor 41 Tahun 2007. Kenyataan yang ditemui di sekolah-sekolah adalah proses pembelajaran yang dilaksanakan tidak efektif yang disebabkan karena belum terpenuhinya secara optimal standar proses yang ditetapkan pemerintah dalam Permendiknas Nomor 41 tahun 2007.

Dampak dari proses pembelajaran akan menghasilkan berbagai konsepsi pada siswa. Konsepsi merupakan deskripsi seseorang (siswa) tentang suatu konsep. Konsepsi yang dihasilkan terdiri dari tiga kelompok yaitu paham, miskonsepsi, dan tidak paham. Perbedaan antara pemahaman yang dibentuk oleh siswa dengan pemahaman yang umum diterima (ilmiah) disebut miskonsepsi. 
Konsep di dalam ilmu kimia merupakan konsep yang berjenjang dari yang sederhana ke konsep yang lebih tinggi tingkatannya, sebagian besar konsep kimia bersifat abstrak. Karakteristik yang dimiliki oleh konsep kimia tersebut dapat menyebabkan siswa mengalami miskonsepsi dan tidak paham.

Tujuan dari penelitian ini adalah mendeskripsikan dan menganalisis proses pembelajaran pada materi sel elektrolisis, menganalisis pemahaman konsep (konsepsi) siswa pada materi sel elektrolisis dan mengetahui penyebab miskonsepsi dan tidak paham siswa pada materi sel elektrolisis. Manfaat dari penelitian ini sebagai bahan masukan bagi guru mengenai gambaran konsepsi yang terjadi dalam diri siswa pada materi sel elektrolisis, sebagai bahan pertimbangan bagi guru untuk merencanakan pelaksanaan pembelajaran yang sesuai agar kesalahan pemahaman pada materi sel elektrolisis bisa diminimalkan, sebagai bahan kajian bagi peneliti lain guna penelitian yang sejenis dimasa yang akan datang.

Pendidikan dan pembelajaran adalah salah satu usaha yang bersifat sadar tujuan yang dengan sistematis terarah pada perubahan tingkah laku menuju ke kedewasaan anak didik (Sardiman: 2010: 12). Perubahan-perubahan itu menunjukkan suatu proses yang harus dilalui. Tanpa proses itu tujuan tidak dapat tercapai. Proses yang dimaksud adalah proses pendidikan dan pembelajaran. Pembelajaran adalah proses interaksi peserta didik dengan pendidik dan sumber belajar pada suatu lingkungan belajar. Pembelajaran merupakan bantuan yang diberikan pendidik agar dapat terjadi proses pemerolehan ilmu dan pengetahuan, penguasaan kemahiran dan tabiat, serta pembentukan sikap dan kepercayaan pada peserta didik. Dengan kata lain, pembelajaran adalah proses untuk membantu peserta didik agar dapat belajar dengan baik. Proses pembelajaran yang dilaksanakan harus berdasarkan standar proses yang berpedoman kepada per- mendiknas Nomor 41 Tahun 2007. Menurut permendiknas ini, standar proses meliputi perencanaan proses pembelajaran, pelaksanaan proses pembelajaran, penilaian hasil pembelajaran, dan pengawasan proses pembelajaran untuk terlaksananya proses pembelajaran yang efektif dan efisien.

Materi pelajaran kimia terdiri dari fakta, konsep dan proses. Van den Berg (2009: 1) menyatakan bahwa dalam pengajaran sehari-hari yang diutamakan adalah konsep. Pendapat ini didukung oleh Ratna (1988: 95) dalam bukunya Teori-Teori Belajar yang menyatakan bahwa hasil utama pendidikan yaitu belajar konsep. Menurut Rosser dalam Ratna (1988: 97) konsep adalah suatu abstraksi yang mewakili satu kelas objek-objek, kejadian-kejadian, kegiatankegiatan, atau hubungan-hubungan yang mempunyai atribut-atribut yang sama. Oleh karena setiap orang mengalami stimulus-stimulus yang berbeda, orang membentuk konsep sesuai dengan pengelompokan stimulus-stimulus dengan cara tertentu. Karena konsep- konsep tersebut adalah abstraksi-abstraksi yang berdasarkan pengalaman, dan karena setiap orang tidak ada yang mempunyai pengalaman yang persis sama, maka konsep-konsep yang dibentuk setiap orang akan berbeda juga.

Tafsiran seseorang dari suatu konsep ilmu disebut konsepsi. Tafsiran/konsepsi siswa mengenai suatu konsep dalam ilmu kimia berbeda dari konsep guru atau buku, walaupun dalam ilmu kimia kebanyakan konsepnya mempunyai arti yang jelas dan sudah disepakati bersama oleh para pakar ilmu kimia (kimiawan). Tetapi kalau konsepsi siswa itu bertentangan atau tidak cocok dengan konsepsi para kimiawan, maka dalam hal ini siswa mengalami salah konsepsi yang disebut dengan istilah miskonsepsi (misconception). Menurut Kirkwood dan Symington (Effendy, 2002: 12) terjadinya miskonsepsi dalam belajar kimia dapat ditinjau dari siswa, pengajar, dan materi pelajaran. Dari segi 
siswa kesalahan pemahaman ini disebabkan pengetahuan yang diperoleh oleh siswa dari hasil belajar sebelumnya, kemampuan berfikir, motivasi belajar, dan kesiapan untuk belajar. Dari segi pengajar miskonsepsi disebabkan karena metode dan media yang digunakan. Sedangkan dari segi materi, miskonsepsi disebabkan karena konsep-konsep yang kompleks dan abstrak serta materi yang terlalu padat.

Treagust (1988: 299) merancang suatu model tes obyektif yang lebih sensitif dan efektif yang dapat digunakan untuk mengidentifikasi miskonsepsi pada siswa. Model yang dikembangkan ini disebut tes diagnostik bertingkat dua atau two-tier diagnostic test. Tes jenis ini terdiri dari dua bagian. Bagian pertama dari setiap item soal merupakan suatu pertanyaan dengan dua sampai lima pilihan jawaban (option). Bagian kedua terdiri dari beberapa pilihan jawaban yang merupakan alasan pemilihan jawaban pada bagian pertama. Dengan menggunakan tes diagnostik bertingkat dua ini dapat diidentifikasi pada konsep mana saja siswa mengalami miskonsepsi. Data yang diberikan oleh siswa dapat dikategorikan menjadi tiga kelompok pemahaman konsep yaitu paham, miskonsepsi, dan tidak paham. Kelebihan dari tes diagnostik ini adalah dapat mengidentifikasi miskonsepsi siswa dalam batas dan konteks yang jelas.

\section{METODOLOGI PENELITIAN}

Jenis penelitian yang dilakukan adalah penelitian deskriptif analisis. Penelitian deskriptif analisis adalah suatu metode penelitian yang ditujukan untuk menggambarkan dan menganalisis fenomena-fenomena yang ada, yang berlangsung pada saat sekarang ini (Nana, 2006: 72). Obyek dalam penelitian ini adalah proses pembelajaran dan pemahaman konsep (konsepsi) siswa. Subyek dalam penelitian ini adalah siswa kelas XII IA I dan IA II serta guru kimia kelas
XII IA. Kelas XII IA 1 (Kelas SSN) terdiri dari 33 orang siswa, kelas XII IA 2 (Kelas Regular) sebanyak 39 orang dan satu orang guru kimia yang mengajar pada kedua kelas. Teknik pengumpulan data yang digunakan adalah teknik tes dan teknik non tes. Teknik tes berupa tes diagnostik bertingkat dua. Tes diagnostik bertingkat dua digunakan untuk mengetahui konsepsi siswa setelah dilaksanakannya proses pembelajaran. Teknik non tes berupa observasi, studi dokumentasi dan wawancara. Observasi, studi dokumentasi dan wawancara digunakan untuk menganalisis proses pembelajaran pada materi sel elektrolisis. Instrumen penelitian yang digunakan adalah alat perekam berupa handycam, lembar observasi dan tes diagnostik bertingkat dua. Penelitian ini dimulai dari menganalisis silabus untuk mengidentifikasi konsep-konsep yang terdapat pada materi sel elektrolisis. Setelah itu dilanjutkan dengan menyusun tes diagnostik dan lembar observasi. Setelah kedua instrumen divalidasi oleh validator, dilaksanakan observasi proses pembelajaran, pemberian tes diagnostik dan wawancara.

Data yang diperoleh dari hasil observasi, studi dokumentasi dan wawancara diolah dengan cara mendeskripsikan dan menganalisis data tersebut sampai diperoleh suatu kesimpulan. Pada tahap perencanaan proses pembelajaran, analisis terhadap RPP guru berdasarkan pada standar proses dalam Permendiknas No. 41 Tahun 2007. Analisis terhadap tahap pelaksanaan proses pembelajaran berdasarkan kesesuaian antara pelaksanaan proses pembelajaran di kelas dengan RPP buatan guru dan standar proses. Pada tahap penilaian, analisis dilakukan terhadap soal ulangan harian yang dibuat guru apakah sudah sesuai dengan tujuan pembelajaran atau belum. Data dari hasil tes diagnostik bertingkat dua diolah dengan cara melakukan pengelompokan dari jawaban siswa sbb: siswa termasuk pada kategori paham jika kedua tingkat jawaban, baik tingkat per- 
tama dan tingkat kedua, memperlihatkan respon yang benar. Miskonsepsi dikategorikan jika siswa memberikan respon yang benar pada tingkat pertama, tetapi memberikan respon yang salah pada tingkat kedua atau sebaliknya. Tidak paham dikategorikan jika siswa tidak memberikan respon atau memberikan respon yang salah pada kedua tingkat. Kemudian menggunakan analisis statistik deskriptif dengan menggunakan perhitungan \% untuk mengetahui besarnya konsepsi siswa.

$$
\% \text { jawaban }=\frac{P}{N} \times 100 \%
$$

Dimana, $\mathrm{P}=$ Jumlah peserta pada kelompok jawaban (paham, miskonsepsi, tidak paham)

$$
\mathrm{N}=\text { Jumlah seluruh peserta tes }
$$

Untuk mengetahui penyebab terjadinya miskonsepsi dan tidak paham, dilakukan analisis dengan menghubungkan hasil tes diagnostik bertingkat dua dengan proses pembelajaran serta hasil wawancara dengan siswa.

\section{HASIL DAN PEMBAHASAN}

Rencana Pelaksanaan Pembelajaran (RPP) yang digunakan guru dalam pembelajaran di kelas XII IA I dan IA II SMAN 1 Panti sudah sesuai dengan RPP menurut permendiknas Nomor 41 tahun 2007. Hanya saja pada RPP tersebut guru tidak mengembangkan materi pembelajaran ke dalam bentuk fakta, konsep, prinsip, dan prosedur yang relevan dengan materi

Berdasarkan analisis terhadap pelaksanaan pembelajaran, pada kedua kelas guru tidak menjelaskan tujuan pembelajaran atau kompetensi dasar yang akan dicapai oleh siswa. Padahal menurut Permendiknas Nomor 41 Tahun 2007 kegiatan tersebut harus dilaksanakan. Dengan dijelaskannya tujuan pembelajaran, siswa akan mengetahui kompetensi dasar apa saja yang harus dikuasainya setelah mempelajari materi sel elektrolisis. Pada kedua kelas guru tidak mengidentifikasi pengetahuan awal siswa. Hal ini menyebabkan banyak siswa IA I dan IA II yang mengalami miskonsepsi dan tidak paham Pada kelas XII IA I guru tidak mereview konsep prasyarat pada materi sel elektrolisis. Oleh karena itu banyak siswa IA I yang mengalami miskonsepsi dan tidak paham. Konsep prasyarat pada materi sel elektrolisis meliputi konsep larutan elektrolit, lelehan elektrolit, dan reaksi redoks. $\mathrm{Pa}-$ da kegiatan inti, guru belum melaksanakan kegiatan yang sesuai dengan standar proses menurut Permendiknas Nomor 41 Tahun 2007. Kegiatan inti yang meliputi proses eksplorasi, elaborasi, dan konfirmasi telah dituliskan dalam RPP guru, tetapi pada pada kenyataannya tidak dilaksanakan.

Berdasarkan observasi terhadap proses pembelajaran, penilaian yang dilaksanakan telah sesuai dengan RPP yang dibuat oleh guru yang berpedoman kepada standar penilaian menurut Permendiknas Nomor 20 Tahun 2007. Berdasarkan analisis terhadap soal ulangan yang dibuat oleh guru, soal tersebut sudah memenuhi persyaratan instrumen penilaian hasil belajar. Isi tes tersebut telah dapat mewakili secara representatif terhadap keseluruhan materi sel elektrolisis.

- Konsepsi Siswa

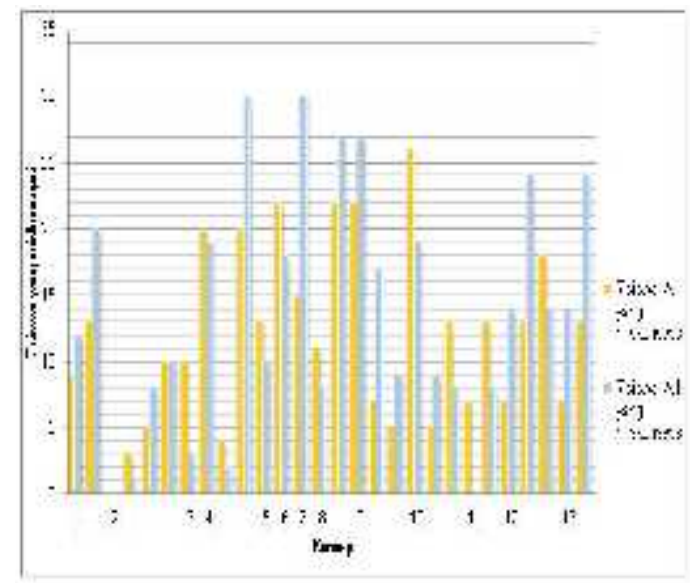

Gambar $\sum$ Siswa IA I dan IA II yang miskonsepsi pada materi Sel Elektrolisis 


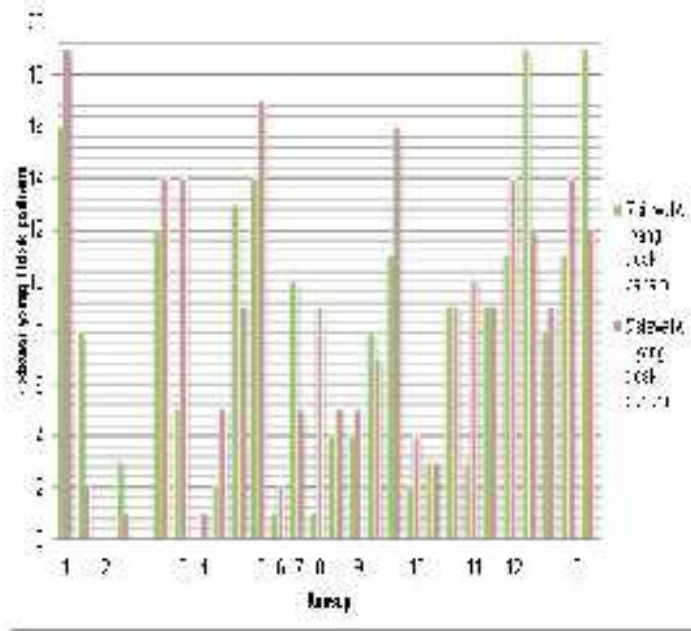

Gambar 2. Jumlah Siswa IA I dan IA II yang tidak paham pada materi Sel Elektrolisis

Keterangan Gambar:

Konsep

1 : Sel Elektrolisis
2 : Larutan Elektrolit

3 : Lelehan Elektrolit

4 : Hukum Faraday

5 : Elektroda

6 : Elektroda Inert

7 : Elektroda Non Inert

8 : Katoda

9 : Anoda

10 : Reduksi

11 : Oksidasi

12 : Reaksi Redoks

13 : Potensial Oksidasi/ Reduksi Standar

Tabel 1. Konsepsi siswa dan penyebab siswa mengalami miskonsepsi dan tidak paham pada materi Sel Elektrolisis

\begin{tabular}{|c|c|c|}
\hline Konsep & Konsepsi Siswa & Penyebab \\
\hline $\begin{array}{l}\text { 1.Sel Elektrolisis } \\
\text { (soal } 8 \text { dan 9) }\end{array}$ & $\begin{array}{l}\text { - Prinsip dasar elektrolisis adalah } \\
\text { terjadinya arus listrik disebab- } \\
\text { kan karena reaksi kimia } \\
\text { - Elektrolisis merupakan peristiwa } \\
\text { penguraian larutan elektrolit } \\
\text { dalam sel elektrolisis meng- } \\
\text { hasilkan arus listrik } \\
\text { - Reaksi pada sel elektrolisis ter- } \\
\text { jadi secara spontan }\end{array}$ & $\begin{array}{l}\text { Kelas IA I dan IA II : } \\
\text { Guru: Metoda guru kurang } \\
\text { efektif } \\
\text { - Penjelasan sedikit } \\
\text { - Prinsip dasar tidak dijelaskan } \\
\text { Siswa: } \\
\text { - Pengetahuan yang diperoleh } \\
\text { siswa dari hasil belajar sebe- } \\
\text { lumnya } \\
\text { - Kemampuan berfikir rendah }\end{array}$ \\
\hline $\begin{array}{l}\text { 2.Larutan } \\
\text { Elektrolit (soal } \\
\text { 1,2,3 dan 18) }\end{array}$ & $\begin{array}{l}\text { - Larutan } \mathrm{CaCl}_{2} \text { dapat meng- } \\
\text { hantarkan arus listrik karena } \\
\text { mengandung molekul yang } \\
\text { bergerak bebas } \\
\text { - } \mathrm{CaCl}_{2} \text { dalam larutannya me- } \\
\text { ngandung ion-ion } \mathrm{Ca}^{+2} \text {, ion-ion } \\
\mathrm{Cl}^{-} \text {dan molekul } \mathrm{CaCl}_{2} \text {, ion- } \\
\text { ion dan molekul inilah yang } \\
\text { menghantarkan arus listrik }\end{array}$ & $\begin{array}{l}\text { Kls IA I : } \\
\text {-guru tidak mereview pelajaran } \\
\text {-Pengetahuan awal siswa rendah }\end{array}$ \\
\hline $\begin{array}{l}\text { 3.Lelehan } \\
\text { Elektrolit(soal } \\
\text { 19) }\end{array}$ & $\begin{array}{l}\text { Pada elektrolisis cairan } \mathrm{Al}_{2} \mathrm{O}_{3} \text {, } \\
\text { selain terdapat ion } \mathrm{Al}^{+3} \text { dan } \mathrm{O}^{-2} \text {, } \\
\text { juga terdapat molekul air }\end{array}$ & 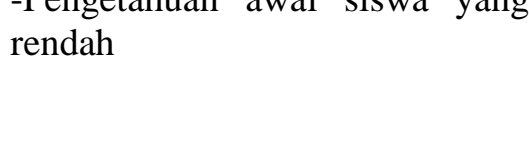 \\
\hline
\end{tabular}




\begin{tabular}{ccccc}
\hline $\begin{array}{c}\text { 4.Hukum } \\
\text { (soal }\end{array}$ & Faraday & -Jumlah massa zat yang dihasilkan & IA I : \\
24) & & pada katoda dan anoda berban- & \\
& & ding terbalik dengan jumlah & - guru hanya menjelaskan se-cara \\
& listrik yang digunakan selama & umum mengenai penerapan \\
& elek-trolisis & hukum faraday \\
& & - guru langsung menjelaskan ke \\
& Pada proses pelapisan sendok dalam bentuk matematika \\
& tembaga oleh perak, sendok & IA II : \\
& tembaga berfungsi sebagai & - Guru tidak menjelaskan me- \\
& anoda dan perak berfungsi & ngenai penerapan hukum \\
& sebagai katoda & Faraday
\end{tabular}

5. Elektroda (soal Dalam elektolisis larutan $\mathrm{CuSO}_{4}$ 16) menggunakan elektroda $\mathrm{Ni}$, yang mengalami reaksi oksidasi di anoda adalah $\mathrm{SO}_{4}^{-2}$

Kelas IA I dan IA II :

Konsepsi guru mengenai konsep elektroda terlalu sederhana

6. Elektroda Inert logam Pt termasuk elektoda non Kelas IA I dan IA II : (soal 12) inert yang ikut bereaksi dengan elektrolitnya.

Guru tidak menjelaskan me7. Elektroda Non $\mathrm{Au}$ adalah elektroda non inert ngenai konsep elektroda inert dan Inert (soal 13) yang tidak bereaksi dengan non inert elektrolitnya

\begin{tabular}{|c|c|}
\hline $\begin{array}{l}\text { 8. Katoda (soal } 10 \\
\text { dan 11) }\end{array}$ & $\begin{array}{l}\text { Katoda adalah elektroda berkutub Kelas IA I dan IA II: } \\
\text { positif dan pada katoda terjadi } \\
\text { reaksi oksidasi. Ion yang bergerak } \\
\begin{array}{l}\text { menuju katoda adalah ion negatif } \\
\text { konsepsi pada pembelajaran se- } \\
\text { belumnya }\end{array}\end{array}$ \\
\hline $\begin{array}{l}\text { 9. Anoda (soal 11, } \\
17 \text { dan 20) }\end{array}$ & $\begin{array}{l}\text { Anoda adalah elektroda berkutub - Guru kurang mengidentifikasi } \\
\text { negatif dan pada anoda terjadi } \text { dan mengoreksi miskonsepsi } \\
\text { reaksi reduksi. Ion yang bergerak } \\
\text { menuju anoda adalah ion positif }\end{array}$ \\
\hline $\begin{array}{l}\text { 10. Reduksi (soal } \\
4,6 \text { dan 7) }\end{array}$ & $\begin{array}{ll}\text {-Reaksi reduksi adalah reaksi pe- } & \text { Kelas IA I dan IA II } \\
\text { lepasan elektron } & \\
\text {-Reaksi reduksi adalah reaksi di- } & \text { - } \\
\text { mana terjadi kenaikan bilangan } & \text { Siswa sudah mengalami mis- } \\
\text { oksidasi pada unsur yang ter- } & \text { konsepsi juga pada pembe- } \\
\text { libat dalam reaksi tersebut. } & \text { lajaran sebelumnya (sel volta) } \\
& \text { Guru kurang mengoreksi mis- }\end{array}$ \\
\hline $\begin{array}{l}\text { 11.Oksidasi (soal } 5 \\
\text { dan 7) }\end{array}$ & $\begin{array}{l}\text {-Reaksi oksidasi adalah reaksi pe- } \\
\text { nangkapan elektron } \\
\text {-Reaksi oksidasi adalah reaksi di- } \\
\text { mana terjadi penurunan bilangan } \\
\text { oksidasi pada unsur yang ter- } \\
\text { libat dalam reaksi tersebut. }\end{array}$ \\
\hline
\end{tabular}




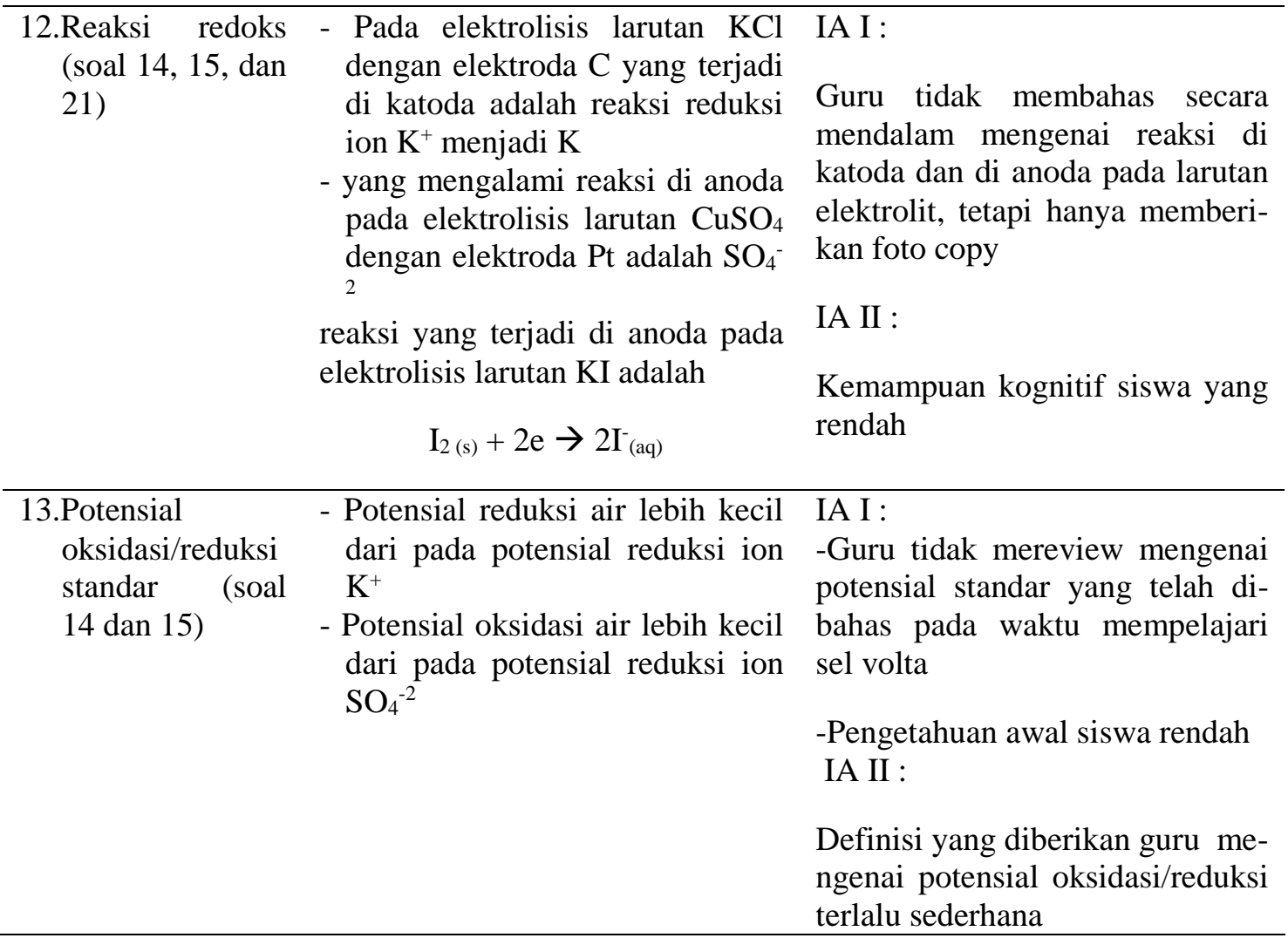

\section{KESIMPULAN DAN SARAN}

Kesimpulan dari penelitian ini adalah Proses pembelajaran yang dilaksanakan oleh guru di kelas XII IA I dan IA II SMAN 1 Panti belum sesuai dengan standar proses menurut Permendiknas Nomor 41 Tahun 2007 meskipun format RPP yang dibuat guru telah sesuai menurut Permendiknas tersebut, Siswa kelas XII IA I dan IA II mengalami miskonsepsi dan tidak paham pada berbagai konsep dalam materi sel elektrolisis, Miskonsepsi dan ketidakpahaman siswa di kelas XII IA I dan IA II SMAN 1 Panti, dari segi guru disebabkan karena metoda guru yang kurang efektif dalam proses pembelajaran, guru tidak menggunakan media dalam mengajarkan materi sel elektrolisis, guru tidak mengidentifikasi pengetahuan awal siswa, guru tidak mereview konsep prasyarat dalam pembelajaran,dan guru lebih cenderung menerapkan belajar hafalan di kelas. Dari segi siswa, miskonsepsi dan ketidakpahaman disebabkan karena kemampuan kognitif, pengetahuan awal, dan motivasi siswa yang rendah.

Berdasarkan hasil penelitian mengenai proses pembelajaran dan konsepsi siswa pada konsep-konsep elektrolisis di kelas XII IA I dan IA II SMAN 1 Panti dapat disarankan agar guru kimia dapat melaksanakan proses pembelajaran sesuai dengan standar proses menurut Permendiknas Nomor 41 tahun 2007, memberikan tes diagnostik pada materi sel elektrolisis segera setelah proses pembelajaran selesai, supaya miskonsepsi dan tidak paham yang dialami siswa dapat teridentifikasi dan segera diberikan tindak lanjut, dalam mengajarkan materi sel elektrolisis meninjau konsepsi awal siswa mengenai konsep larutan dan lelehan elektrolit, reaksi reduksi dan reaksi oksidasi, sebab konsep-konsep tersebut merupakan konsep prasyarat untuk mempelajari materi sel elektrolisis. 


\section{DAFTAR RUJUKAN}

Anas Sudijono. 2009. Pengantar Evaluasi Pendidikan. Jakarta: PT. Rajagrafindo Persada.

Effendy. 2002. Upaya untuk mengatasi kesalahan konsep dalam pengajaran kimia dengan menggunakan strategi konflik kognitif. Media komunikasi kimia, Jurnal Ilmu Kimia dan Pembelajaran, 2(6)1-22

Muhammad Halomoan. 2010. Persepsi Guru Fisika Terhadap Konsep Gaya Pada Benda Diam Dan Bergerak. (Online) (http://www. jurnalanalisis miskonsepsi.com, diakses 3 Mei 2010).

Nana Syaodih S. 2006. Metode Penelitian Pendidikan. Bandung: PT Remaja Rosdakarya

Nengah Maharta. 2010. Analisis Miskonsepsi Fisika Siswa SMA di Bandar Lampung. Bandar Lampung: FKIP Unila

Nur Afifuddin. 2009. Penggunaan Model Pembelajaran Konstruktivisme Dalam Meminimalkan Miskonsepsi Siswa Untuk Mata Pelajaran Fisika di SMP 3 Jekulo Kudus Tahun Pelajaran 2008/2009. (Online) (http://www.jurnalanalisismiskons epsi.com, diakses 3 Mei 2010).

Permendiknas RI Nomor 41 Tahun 2007 Tentang Standar Proses Untuk Satuan Pendidikan Dasar dan Menengah. (Online) (http://www .permendiknas41.com, diakses 3 Mei 2010)

Permendiknas RI Nomor 20 Tahun 2007 Tentang Standar Proses Untuk Satuan Pendidikan Dasar dan Menengah. (Online) (http://www .permendiknas20.com, diakses 3 Mei 2010)

Ratna Wilis Dahar. 1988. Teori- Teori Belajar. Jakarta: Depdikbud Dirjen Pendidikan Tinggi, Proyek Pengembangan Lembaga Pendidikan Tenaga Kependidikan.

Treagust, D.F. 1988. Development and Use of Diagnostic Test to Evaluate Student's Misconception in Science. International Journal Science Education.10 (2)159-169

Treagust, D. F. 2006. Diagnostic Assessment in Science as a Means To Improving Teaching, Learning and Retention. Uni Serve Science Assessment Symposium Proceedings 1-9. 